\title{
Noticeboard
}

\section{Politics and Art}

Two very interesting softcover books have recently been published which deal with aspects of the interaction of politics and art. Ant in Yugoslavia 1992-1995 is primarily the catalogue of a travelling exhibit which was shown in London in March 1997 , but the front part of the catalogue is made up of two interesting essays. The first, by Dejan Retenovic, is entitled 'Art in a Closed Society', and considers comparatively the concepts of post-Modernism and post-Communism. He argues that, in the circumstances of Yugoslavia, art cannot be the mirror or corrective of society but 'solely the signal of some other, parallel reality originating in permanent tensions between harsh living conditions and individual fantasy'. The second essay, by Lidija Merenik, is entitled 'No Wave: I992-I995'. In it she tries to define the dominant characteristic(s) of contemporary art in general and Yugoslav art in particular during this period; while so doing, she gives an overview of some of the major Yugoslav trends and artists. The second part of the catalogue is made up of photographs, many in colour, of works from the exhibition. The third part of the catalogue is a chronology covering significant exhibitions, publications and prizes. Finally, the last section gives brief biographies of the artists involved in the exhibition. It is published in both Serbian and English by the Fund for an Open Society and the Center for Contemporary Arts, 29, novembra Ia, I Iooo Beograd, Yugoslavia, tel/fax (38I) I I 343879 .

Styles, Struggles, and Careers: An Ethnography of the Czech Art World, 1948-1992 is the thesis by Maruška Svašek on which she based the article which appears in this journal. The foundation of her work was the more than one hundred interviews she conducted with Czech visual artists, and, trained as an anthropologist, she combined the approaches of history and anthropology to produce a pathbreaking work, of interest to political and cultural historians alike. The thesis, published in English, is illustrated with photographs of thirty-three art works. For further information write to the Amsterdam School for Social Science Research, Oude Hoogstraat 24, IOI2 CE Amsterdam, the Netherlands, email ASSR@PSCW.UVA.NL, tel. no. +3 I 205252262 , FAX no. +3 I 205252446. 


\title{
Conference
}

\section{848: A EUROPEAN REVOLUTION?}

University College London, Centre for European Studies, (with the support of the German Historical Institute, London)

February 1998

The conference looks at the Revolution of 1848 from two perspectives: first, the European dimension of the ideas of the 1848 revolution, with the aim of analysing both the centres and the periphery; and second, the political and social function of European commemorations of 1848 in the last I 50 years.

Details can be obtained from:

Dr Axel Körner

Department of History

University College London

London WCrE 6BT

Tel. no. $+44-I 7 I-4 I 9-36 I 7$

FAX no. $+44-17 \mathrm{I}-4 \mathrm{I} 3-8394$

email: a.korner@ucl.ac.uk

\author{
NATO - The First FifTy YeARS \\ From 'Security of the West' to 'Securing Peace in Europe' \\ Location to be determined (probably at Brussels/NATO) \\ March-April 1999
}

This four-day conference is being organised by Gustav Schmidt, Chair, International Politics, at Ruhr-University Bochum, Germany and J. L. Granatstein, Resident Fellow, Canadian Institute of International Affairs, Toronto, Canada. The programme is the product of a pre-conference held at the Werner Reimers-Stiftung, Bad Homburg, 28 July-2 August 1997. The participants there have agreed to be chairs of sessions and keynote speakers; agendas for each section were debated and decided at Bad Homburg and consist of a set of propositions setting out key issues in each area.

The convenors and session chairs will invite two or three experts to present papers in each session; at least two slots in each session will be filled from those responding to the Call for Papers. These papers will be published in book form on the eve of the Conference; good papers not selected for presentation may be posted at the Conference.

Abstracts and papers must be submitted in English or French.

The convenors seek papers from historians and from scholars in related disciplines such as political science and international law. 
Those wishing additional details should write to either J. L. Granatstein, 53 Marlborough Ave., Toronto, Ont. MsR IXs, Canada (e-mail: jlgranat@yorku.ca), or Gustav Schmidt, Lehrstuhl International Politik, Ruhr-Universität Bochum, Geb.GC 04-705, D-44780 Bochum, Germany (e-mail: Gustav.Schmidt@ruhr-unibochum.de).

Those interested in participating should indicate the session in which they wish to participate; the agenda for that session will then be provided. Abstracts and papers must be sent to both convenors. The deadline for submission of an abstract (two papers maximum) is I March I998; those chosen for conference presentation must submit drafts by 3 I July 1998; the final papers, going to press on I December I998, must be in the convenors' hands by I November 1998. All deadlines are firm.

\section{Programme}

Plenary Session (to be held one per afternoon)

I. Nuclear Issues (Chair: Wolfgang Krieger, Marburg)

2. NATO After the Cold War: Reform and Restructuring (Chair: Kori Schake, San Diego)

3. NATO and EU/WEU (Chair: Gustav Schmidt, Bochum)

4. NATO Enlargement (Chair: J. L. Granatstein, Toronto)

Parallel Sessions (three to be held simultaneously each morning)

I. The Origins and Meaning of NATO Membership (Chairs: Robert Bothwell, Toronto; Saki Dockrill, London)

2. NATO and the Warsaw Pact (Chair: D. Beatrice G. Heuser, London)

3. NATO and Intra-West Tènsions (Chair: Frédéric Bozo, Paris)

4. NATO and the United Nations (Chair: Lawrence Kaplan, Washington)

5. NATO Military Strategy and Force Structures (asked: Norbert Wiggershaus, Potsdam)

6. NATO and Out-of-Area Problems (asked: Mats R. Berdahl, Oslo)

7. NATO and the Southern Flank (Chair: Leopoldo Nuti, Rome)

8. The Atlantic Community: Transatlantic Relationships (Chair: Paul Buteux, Winnipeg)

9. Commitment to NATO and Domestic Politics (Chair: Anne Deighton, Oxford)

ro. Arms Procurement, Production, and Exports (asked: Trevor Taylor, Nottingham)

I I. NATO, the Northern Flank and the Neutrals (Chair: Olav Riste, Oslo)

I2. NATO History: Methodology and Sources (Chair: Bruce Pedlow, SHAPE)

There will also be conference dinner speakers and other public fora. 